\title{
The Inca healer: empirical medical knowledge and magic in pre-Columbian Peru
}

Jan G. R. Elferink

Leiden University, Holanda

The role of medical practitioners among the Incas is addressed, based on archeological findings and especially the writings of the Spanish chroniclers. In Inca medicine a large role was reserved for religion and magic but at the same time an extensive knowledge of medicinal plants was available. As a consequence there were several types of healers who cured with a mixture of medicinal plants and religious-magic ceremonies. The hampicamayoc or 'official in charge of medicines' was the one who resembled somewhat the European physician of that time and was the most important type of healer. He relied largely but certainly not exclusively on the use of medicinal plants. There were also healers who cured mainly with religious-magic procedures. Surgery must have been important for the Inca healer but this is hardly reflected in the work of the Spanish chroniclers.

KEY WORDS: Inca; healer; medicine; magic; hampicamayoc.

\section{INTRODUCTION}

The Incas represented the last of many highly developed indigenous cultures which existed along the Pacific coast and in the Andean highlands of South-America. At the time of the conquest the Inca empire stretched from Colombia in the north till mid-Chile in the south. There is a reasonable amount of information about some aspects of Inca medicine, such as the application of medicinal plants. About other aspects of Inca medicine we are far less informed and that also applies to the Inca practitioners of medicine which will be here denoted as healers. The name healer is used here in a very broad sense and 
means a medical practitioner who treats illness and makes attempts to cure a patient. This may occur by applying medicinal plants but also by performing surgical operations, or with magic, religious incantations and prayers. In this regard the Inca healer differs from the modern physician who has a detailed knowledge of academic disciplines such as anatomy and physiology. However, round the beginning of the sixteenth century less or more the same was true for the European physician who did not know all too much of these academic disciplines and would probably have been called a witch doctor, judging from a modern point of view.

Because none of the pre-Columbian South American civilizations knew to write only two major sources of information are available for the study of Inca medicine. Archeological findings represent one group. An example is the skeletal remains which can give information about some diseases, surgical treatments and medicine-related customs such as cranial deformation. The written reports of the Spaniards who accompanied or followed the Spanish conquerors are the other source of information. This source is quite important but has a few serious disadvantages. One disadvantage is the relatively late publication of these works, sometimes many years after the conquest. Another disadvantage is the prejudice of many Spaniards with regard to aspects of Inca society which had a relation with religion and magic because that was considered as inferior, wrong and/or the work of the devil. ${ }^{1}$ That was particular true for the Catholic priests among the chroniclers but exactly this group provided a lot of information about the Incas. Because Inca medicine as well as the medical practitioners had many links with magic and religion the reports about these items has to be considered with some suspicion.

In this paper the role of the indigenous healer in Inca society is described, based on the data available in the post-conquest written sources and from archeological findings. Because religion and magic played a decisive role in

${ }^{1}$ For information about Inca healers the work of the chroniclers is far more important than that of archeological findings. This presents a special problem because many chroniclers were priests and their reports about healers might have been influenced by their rejection of magic-religious influences which played a significant role in Inca medicine. Furthermore, the way how they collected information played also a role. This however, could be very complex. The chronicler Cobo is a good example. He was a Jesuit who visited many parts of Peru. During his stay in Cuzco he obtained information about the ancient Inca history from what had remained of the old Inca nobility (Prieto, 2011: 101. Hamilton, in: Cobo, 1990: XIV, $\mathrm{XV}$ ). After his stay in Cuzco he was sent to the area round Lake Titicaca. It seems likely that Cobo received his information about healers mainly from the Indians in the region where he was. However, Cobo (and other chroniclers as well) copied also information from previous chroniclers. His description of the midwife, for example, is copied from the work of Polo (Cobo, 1964: 13-XXXV. Polo, 1916: 35). 
all aspects of Inca life, their role in the medical profession will be addressed, as well the empirical knowledge of medicinal plants and surgery. The paper starts with a discussion of concepts in Inca medicine, followed by an overview of the different types of indigenous healers in ancient Peru and their ways of curing. The most important one of this group, the hampicamayoc, is dealt with in a separate next section. Surgery, surgeons and trepanation are the subject of the following sections, followed by a general discussion about the role of the healer in Inca society.

\section{CONCEPTS IN INCA MEDICINE}

The Incas had some specific ideas about the pathogenesis and the course of a disease which were completely different from the modern western view of medicine. These ideas are essential for the understanding of Inca medicine in general and the role of the healer in particular. They are the cause that the Spanish chroniclers often wrote in a negative sense about the medical practitioners of Peru. While the profound knowledge of medicinal plants was experienced by the Spaniards as a positive feature, the large and intimate involvement of religion and magic in Inca medicine and its practitioners was a feature that did not contribute to its popularity among the western invaders. For the Incas a close relation existed between religion and magic on one side, and disease on the other. Disease was seen as the result of a disturbed relationship with supernatural forces. A number of reports support this hypothesis. One of the most direct statements concerning the association between religion and disease comes from Polo:

...they were of the opinion that all diseases were a consequence of the sins they had committed. And as a remedy they made sacrifices, and furthermore they made confessions in nearly all provinces... this confession they also made when their children, wives or cacique went ill... ${ }^{2}$

Disease of the ruler, by Polo indicated with the name cacique, was thought to be caused by the sins of the common people. The Incas (as well as the Aztecs in Mexico) practiced a confession that was of pre-Hispanic origin and which was made to specific priests, the $y$ churi. ${ }^{3}$ As a consequence of the belief

\footnotetext{
2 Polo, 1916: 12.

${ }^{3}$ The name ychuri was the most common indication for the priest who took confession and was used in Cuzco and in the Collasuyo province. However, in some parts of the empire confession was made to others such as the $u m u$, by the Spaniards described as a kind of 'sorcerer', (Morua, 1946: 159) or to the huacapvillac (Arriaga, 1968: 205).
} 
that sin was a cause of disease the making of a confession was considered as an effective means to cure diseases. ${ }^{4}$ Garcilaso relates that the Incas thought that sickness, death and famine were the consequences of their sins and faults. Cieza de León reports that an Indian, who felt ill, made offerings, as they had learned from their ancestors. ${ }^{5}$ Most chroniclers were not interested in the relation between sin and disease, but more in Inca confession. The catholic Spaniards were well acquainted with the practice of confession, and were somewhat surprised that the Incas had a comparable custom. This confession was primarily practiced in time of disease, because cleansing the sin meant that as a consequence the diseased person would recover. About the relation between disease, sin and confession Arriaga is very clear:

...besides during the festivities [in honor of the huacas] they use to make confessions when they are ill. They make them to the same sorcerers in the way as described before. The reason for this is that they believe that their sins have disturbed the malquis and the huacas, and that as a consequence they themselves are becoming ill...6

For the Incas supernatural forces were not only associated with gods, but also with a large number of material objects such as stones, buildings, burial places, plants, humans and so on. These sacred objects were called huacas. ${ }^{7}$ They were very numerous and varied in form and importance. Strangely formed stones were particular popular as huaca. Malquis were the remains of the ancestors. Apparently these ancestors were supposed to possess some form of supernatural power after their death. They were venerated in the same way as the huacas.

An idea about the origin of diseases that in Latin America has persisted after the conquest and up to modern times was the belief that sorcery could be the cause of a disease. Among the severe sins that were confessed was not only murder and adultery, but also causing diseases by giving herbs or by

${ }^{4}$ Arriaga, 1968: 206-212. Garcilaso, 1966: 97. Murua, 1987: 411-412. Acosta, 1979: 259-262.

5 Cieza de León, 1962: 84-86.

${ }^{6}$ Arriaga, 1968: 213.

${ }^{7}$ Huacas were thus concrete objects which were venerated by the community. The supernatural force could not be separated from the object. The Spaniards made use (or abuse) of this property by destroying the object because then the supernatural force was equally destroyed. Before the Spaniards the Inca rulers made a more subtle use of the same property. When they had conquered a tribe, the main huaca of that tribe was transferred to Cuzco where it was brought in a certain temple. Valera relates that these huacas were even chained. In this way they could not be taken away but it was also a reminder to the people of the region where the idol came from. Valera, 1992: 59. 
sorcery. ${ }^{8}$ The word sorcery will be used here as it was used in the Spanish reports from the sixteenth century. At that time the word has a broader meaning than it has now. The term sorcery was used by the Spaniards indiscriminately, not only to indicate the application of black magic to cause harm but also for divination to forecast the future or to make a diagnosis in case of diseases, the administration of poisonous plants to cause damage, and further for all actions associated with Inca religion. In a number of cases it is therefore not possibly whether only magic was applied to cause diseases, or that 'magic' was mixed with the administration of poisonous plants.

The Incas were convinced of a strong involvement of religion and magic, not only in medicine but also in nearly all other aspects of life. This had a number of consequences. The belief that supernatural forces could be manipulated to give information about hidden or future events resulted in a disproportional interest for divination. This is illustrated by the presence of innumerous diviners of different types which indicates that the Incas had a strong wish to know future events and hidden information. ${ }^{9}$ For the Incas nearly all important and less important events, including diagnosis and prediction of the outcome of a disease, were preceded by divination. The use of psychoactive substances facilitated the contact with supernatural forces who were thought to give information about future and hidden events among which the cause and course of disease Finding the cause of sorcery that had led to a disease, or the answering of the question whether a sick person would recover or die, were only a few of the many applications of divination. Divination was made for the succession of the ruler, to answer the question whether and when a war had to be made, for the finding of criminals, to determine the time of sowing and harvest and in many other aspects of daily life and for that purpose there were many different types of diviners. The belief that supernatural forces had a major role in the origin of a disease was the cause that the indigenous healer had little or no interest in anatomy or physiology. In line with this belief about the role of supernatural forces, the treatment of a disease consisted, at least partly, of a religious-magic approach. Because the Spaniards detested all what was related with Inca magic and religion the description of the Inca healer is often not flattering. The rejecting role of the Spaniards towards the role of religion and magic in Inca medicine was solely due to their own belief in the inferiority of Inca religion because the Spaniards equally believed that prayers and the Catholic saints and could help to cure diseases.

\footnotetext{
${ }^{8}$ Acosta, 1979: 5 y 259-262. Elferink, 1999: 339-360.

9 Acosta, 1954: 172. Cobo, 1990: 160-163. Calancha, 1974: 855. Morua, 1946: 72. Relación de los Agustinos, 1992: 8. Cabello Valboa, 1951: 287.
} 
A few statements give additional information of the Inca view on disease and recovery. Murua writes that the Indians feared death greatly. The same is suggested by Cobo who says that people were convinced that appropriate offering could restore health. Some people were prepared to sacrifice their own children in return for their own health. Even if the latter statement is somewhat exaggerated, it indicates two things. First, the Indians were convinced that religion-magic played a decisive role in disease and cure. Second, the Indians were afraid of death, and that means that priest-magician-healers played a significant role in Inca life. ${ }^{10}$

\section{THE DIFFERENT TYPES OF PRACTITIONERS OF MEDICINE}

A search through the reports of the chroniclers indicates that there were many types of healers among the Incas (Table 1). The Inca ideas about the origin of diseases meant that for the cure of a disease primarily the disturbed relation with supernatural forces had to be restored. All cures were accompanied by offerings and prayers, and diagnosis and prognosis were usually determined by divination. ${ }^{11}$ The latter procedure was connected with the belief that supernatural forces were involved in the cause of the disease. Because it was often assumed that a person had caused the disease by magic spells divination was carried out to find out which person was responsible. ${ }^{12}$ The Incas were quite aware of the benevolent action of medicinal plants and for some types of healers the use of medicinal plants was the main part of their treatment of diseases. However, even these healers did not perform their cures without prayers or magic incantations. Because the relative amount of religion, magic and medicinal plants in a cure were dependent of the preferences and abilities of the curer, there were many types of medical practitioners. On one side of the scale were the healers who were more priests than healer, and on the other side were herbalists who had a large knowledge of medicinal plants. These herbalists, often denoted with the name hampicamayoc, were praised by the Spaniards. They will be discussed in the next section because they were probably the most important type of medical practitioners.

In Table 1 an overview is given of the different types of healers who have been described by the chroniclers. Although the Spanish reports about the Incas

\footnotetext{
${ }^{10}$ Morua, 1946: 77. Cobo, 1964: 206-207. The names Morua and Murua are (and especially were) used in Spanish for the same person. At present the name Murua is preferred.

${ }_{11}$ Murua, 1987: 416.

12 Cobo, 1964: 225-227.
} 
are of lower quality that those about the Aztecs, the linguistic information is good and that information is included into the Table. Quechua was the main and official language of the Incas while Aymara was a kind of second language that was spoken by a large part of the population in the south-eastern part of the empire. The oldest Quechua dictionary is from Fray Domingo de Sancto Thomas while the most informative dictionary that of Diego Gonçález Holguín was published in 1608. Ludovico Bertonio published an Aymara dictionary in 1612. These dictionaries are highly valuable for all studies about the Incas and contain a number of words related to the medical profession.

Table 1. Indigenous (Quechua, Aymara) names for the InCa healer

\begin{tabular}{|c|c|c|}
\hline Indigenous name: & Description: & Ref: \\
\hline Ambicamayo & Witch doctor (=hampicamayoc) & Ar-238 \\
\hline Camasca & Healer-magician & Co-13-XXXV \\
\hline Camasca osoacoyoc & Healer & $\mathrm{Mu}-416$ \\
\hline Chukri hampicamayok & Surgeon & G-470 \\
\hline Chukrihampik & Surgeon & G-470 \\
\hline Circay camayok & Surgeon (for bleedings) & G-84 \\
\hline Colla camana & see: collacamana & B-161 \\
\hline Collacamana & Surgeon, healer & B-161, 311 \\
\hline Collayoc & Herbalist & P-285 \\
\hline Hambi camayoc & Medical practitioner & P-166 \\
\hline Hanpi camayoc & Healer, surgeon & G-145 \\
\hline Hampicamana & Healer & B-311 \\
\hline Hampipayak & Priest-healer & G-145 \\
\hline Hanpiyoc & Healer for criminal practices & P-247, 285 \\
\hline Huachachicuk & Midwife & G-616 \\
\hline Huachachik & Midwife & G-616 \\
\hline Huahuachiti & Midwife & B-396 \\
\hline
\end{tabular}


Table 1. Indigenous (Quechua, Aymara) names for the Inca healer (continuación)

\begin{tabular}{|l|l|l|}
\hline Indigenous name: & Description: & Ref: \\
\hline Macsa & Magician-priest & Ar-206 \\
\hline Moscoc & Diviner & Ar-206 \\
\hline Oquetlupuc & Equivalent of hampicamayoc & Ca-855 \\
\hline Runa uatoc & Diviner & P-285 \\
\hline Sircaeamana & Surgeon & B-320 \\
\hline Soncoyoc & Healer-magician & Co-13-XXXV \\
\hline Viha & Synonym of macsa & Ar-206 \\
\hline Yacarca (or: yacarcae) & Sorcerers, diviners & Mo-64 \\
\hline Yanavillca & $\begin{array}{l}\text { Priest, wise man who supervised the } \\
\text { distribution of medicines }\end{array}$ & V-88 \\
\hline Ynca uatoc & Diviner of the Inca [ruler] & P-285 \\
\hline Yocachiyri & Midwife & B-396 \\
\hline
\end{tabular}

References: abbreviated name-page number, or book and chapter.

Abbreviations: Ar: Arriaga, 1968; B: Bertonio, 1612; Ca: Calancha, 1974; Co: Cobo, 1964; G: Gonçalez Holguín, 1952; Mo: Molina, 1989; Mu: Murua, 1987; P: Poma de Ayala, 1980; V: Valera, 1992. ${ }^{13}$

From some names of Table 1 it is clear that they are synonyms but for others it is not clear whether they were synonyms or really different types of medical practitioners. Oquetlupuc was used in the coastal region and was not a Quechua name but was less or more the equivalent of the hampicamayoc of the Incas. ${ }^{14}$ About some names, such as yanavilca, we know little. The yanavilca was in charge of the distribution of medicines and it was the name of priests who were below the rank of vilca. The latter was seen by the Spaniards as a

${ }^{13}$ Because the Incas did not know to write, the words were written by the Spaniards as they heard them. This resulted sometimes in slightly differently written words in different works. The words derived from the Quechua or Aymara dictionaries come furthermore from the original works and are thus old-Spanish.

14 Calancha, 1974: 855. 
kind of bishop. ${ }^{15}$ Some names of Table 1 could have several meanings. For example, the name yanavilca was not only used for distributors of medicines but it was also the name of one of the leaders of the Chanca army which threatened the Inca state in the fifteenth century. The nature of the ynca uatoc is obscure. Although the literal translation is 'diviner of the Inca ruler', Poma de Ayala gives a very negative picture of his job and reckons them under the sorcerers who deserved death penalty. Ambicamayo is probably a synonym of hampicamayoc but Arriaga stresses the use of magic and religion in the approach of the ambicamayo while most sources stress the knowledge of medicinal plants of the hampicamayoc. ${ }^{16}$

In several reports no Quechua name of a healer is given but they provide nevertheless information about medical practitioners. An example is Cobo who underlines the importance of the knowledge of medicinal plants for the profession:

...their healers were in general old people and highly experienced... they had little knowledge about the nature of the diseases and about their specific names... they did not know the cause, and hardly the effects of the ailments...the most they knew about diseases associated with cold, from which they suffer much... and (they knew) many herbs to cure them. They had more knowledge about wounds and sores... and the particular herbs to cure them. They never used complex drugs, they cured with simple herbs, and between them there were many great herbalists... from whom we learned the virtues of many plants which we now use in our cures. With these simple drugs they also used to make fomentations and perfumes, which they applied against fever and other ailments...they also knew the advantages of bloodletting and purgation, but they did not know to take the pulse or to look at the urine... ${ }^{17}$

In the foregoing description Cobo does not give the indigenous name of this type of herbalist-healer. On another place in his work, as well as in the work of other chroniclers, several names are mentioned for those who were using medicinal plants, but then the description is mostly not flattering. Some chroniclers, such as Cieza de León, call them great sorcerers and herbalists, indicating that in his eyes there was a close relationship between some sorcerers and herbalists. ${ }^{18}$ In his chapter about sorcerer-healers and superstitions Cobo and others mention the camasca or soncoyoc as healers who cured with a mixture of magic and medicinal plants. From their descriptions it appears

15 Valera, 1992: 71.

16 Poma de Ayala, 1980: 285. Arriaga, 1968: 238.

17 Cobo, 1964: 256-258.

18 In anthropology sorcery is usually defined as the practice of performing magic by using the power of evil spirits. The Spanish chroniclers however, used the word in a broader sense. In their view sorcery included also malevolent practices by using poisonous plants, divination, and especially many aspects of religion. Priests were often denoted as 'sorcerer'. 
that among this type of healers there were some who used poisonous plants to harm others. ${ }^{19}$ The way to become a camasca raises the suspicion that his knowledge of diseases and plants was limited because they told that either the thunder had taught them how to act as a healer, or that they had obtained the mission to become a healer in a dream. The word camasca had a broad meaning because its description varies according to the source. Some camascas were little estimated and many of them became sorcerer-healer because they were very poor. The information comes from Polo who adds that there were many poor people in Peru thus also many sorcerer-healers of this type. The involvement in medicine of the camasca is not given in the work of Poma de Ayala. In one place he calls the camasca a philosopher and on other places he describes the camascacona (the plural form of camasca) as priests to whom confessions could be made. In this way the camascacona resembled the laycacona which were equally priests-sorcerers who made divinations and who were involved in taking confessions and in ceremonies during burials. Confession could be made to several types of priests but the most common type was not the camasca but the ychuri. ${ }^{20}$

The macsa or viha was equally a type of medical practitioner who primarily used magic to cure diseases:

...Macsa or viha are those who cure with thousand lies and superstitions. In their usual method they bring offerings to the huaca, or to the conopa of the person who consulted them... they are most damaging because they are consulted for all cases and because they talk with the huacas... ${ }^{21}$

While the huaca was a sacred material object that was venerated by the community, a conopa was a sacred object that belonged to a particular person and that was only venerated by that person. The talking with the huacas meant that the macsas practiced divination and that did not contribute to their popularity among the Spanish priests like Arriaga. ${ }^{22}$

People went to the moscoc to obtain an answer to the question whether a diseased person would survive or die. The moscoc was a diviner who asked for a hair or a piece of clothes of the person and went to sleep with that object under his pillow. When he awoke he divined according to what he had dreamed. Although he made a prognosis for diseased people the moscoc was

19 Cobo, 1964: 227-229. Polo, 1916: 195. Cieza de León, 1962: 69-72. Molina, 1988: 63, 64.

20 Polo, 1916: 12 y 26-27. Poma de Ayala, 1980: 57-160. Valera, 1992: 77.

21 Arriaga, 1968: 206.

22 Some huacas received a specific name which was used instead of huaca. Examples are the vilca, which was a huaca that served as an idol and the conopa. The conopa was usually a small object that served as a kind of guardian angel to protect its owner. 
primarily a diviner rather than a healer. People went also to the moscoc when they had problems in love affairs or when they had lost some goods. ${ }^{23}$

Apart from the knowledge of plants and surgical abilities the Spanish reports stress some other skills of the Inca healers. One of these was the healing of broken or dislocated bones. Cobo even suggests that it was a special class of the healers who were engaged in this field and writes that these specialists gave a lot of care and attention to the patient. ${ }^{24}$ The healing procedure, which was mainly on an empirical base, had also religious aspects because the healer made offerings on the place where the fracture had occurred. A number of medicinal plants were applied against fractures and dislocations. More than twenty plants have been described for this purpose. The plants were mostly applied as a plaster on the location of the fracture or dislocation. Another area where the Inca healers were very experienced was the treatment of wounds, ulcers and other cutaneous disorders. ${ }^{25}$ It seems likely that there was a very practical background for the experience of the healers in the treatment of fractures and wounds and the large number of medicinal plants that were applied to treat these ailments. The large empire was the result of frequent and successful warfare. Some frequently used arms in Andean warfare were clubs, slings, arrows and other objects which were sent to the enemy, and vice versa. The use of these types of weapons results in severe fractures and wounds, and very often in serious injuries to the head.

A class of magician-herbalists about which varying stories have been reported, were the yacarcas. They came from the region of Huaro $(50 \mathrm{~km}$ south of Cuzco) and were feared by everyone, even by the Inca ruler. These yacarcas were primarily known as diviners who were mainly consulted to find out where thieves, murderers or adulterers were located. In their divination practices they used fire as an intermediate. In order to make forecasts from the fire or smoke during burning a few materials were used to burn, especially the fat of llamas and coca leaves. ${ }^{26}$ The yacarca had however, also another specialty, namely the knowledge of poisonous plants:

...when someone escaped from a river or a large danger, they said that the devil appeared to him and to those who wanted to cure with herbs he it learnt them and as a consequence there are many Indians who are famous herbalists. To others he learnt about the poisonous herb with which people could be killed, and those were called yacarcaes... ${ }^{27}$

\footnotetext{
23 Arriaga, 1968: 206.

${ }^{24}$ Cobo, 1964: 206-207. Murua, 1987: 417.

25 Murua, 1987: 256-258.

${ }^{26}$ Cobo, 1964: 225-227.

27 Molina, 1989: 64.
} 
Many Spaniards denoted all deities of the Incas as 'devil', irrespective of their nature. The indigenous informants of Molina will certainly not have used the word 'devil', because the devil as the Spaniards saw him was not known by the Incas. The neutral indication 'spirit' would have been more appropriate.

Among the Incas both males and females could exert the profession of healer. But there was one exception: the assistance in pregnancy childbirth was the exclusive domain of females. The Quechua name for these midwives was huachachik or huachachicuk, while in Aymara language their name was huahuachiti or yocachiyri. ${ }^{28}$ The Spanish reports about them are negative. Cobo mentions some reasons why someone could become midwife. Some were told in a dream that they were given the task to assist in childbirth. A poor woman who gave birth to a twin often decided to become a midwife. Midwives performed offerings, ceremonies and fasting to ensure a good delivery. The description of the midwives by the chroniclers is not exactly flattering. They cured the pregnant woman, and corrected the position of the fetus by massaging the belly. They knew the plants that facilitated childbirth but they used that knowledge also to procure abortion. Together with physical appliances they had therewith the abilities and the means to kill the fetus in the body of the mother. The description by Murua is representative for the attitude of the Europeans towards the Inca midwife:

....among them there were also midwives who told that they had received their vocation and the abilities for the job in their dreams. These women knew how to cure pregnant women and they corrected the position of the fetus. They killed the fetus inside the mother when they were asked to do so, for which they were paid generously... because if a pregnant Indian woman did not want her baby to be born, for fear for her parents or for shame or for other reasons, the only way out was to go to these midwives who caused abortion with herbs, beverages and even with bloodletting and buried the child on secret places... ${ }^{29}$

Abortion was severely punished in ancient Peru, but many chroniclers mention that it occurred regularly. The assistance during abortion was a dangerous task, not only for the woman who underwent abortion, but also for the midwife, for both were punished with death if their behavior was discovered. An important reason for the midwife to assist in committing abortion was the circumstance that they were appropriately rewarded. ${ }^{30}$

${ }^{28}$ Cobo, 1964: 13 y 224-229. Gonçalez Holguín, 1952: 616. Bertonio, 1612: 396.

${ }^{29}$ Murua, 1987: 417.

30 Albornoz, 1988: 176. Valera, 1992: 28-57. Polo, 1916: 35-41. Cobo, 1964: 220-233. Murua, 1987: 417. The attitude towards abortion was the same among Spaniards and Incas: it was strongly abhorred. Cristobal de Albornoz says that Inca women took many herbs to induce 


\section{Hampicamayoc}

A few reasons can be put forward from which it seems likely the hampicamayok was an important if not the most important type of healer among the Incas. In his dictionary of Quechua language Gonçalez Holguín gives hampi camayoc as translation of 'medico', the Spanish equivalent of physician. When Calancha reported about the medicine of the coastal regions where in former times the Chimús were the rulers he calls the healer oquetlupuc. ${ }^{31} \mathrm{He}$ adds that they were called hampicamayoc in the Andean regions, thus the heartland of the Incas. Besides Gonçalez Holguín and Calancha some other chroniclers use the name hampicamayoc or a related form when they deal with Inca medical practitioners suggesting that the word hampicamayok is the most common indication for the Inca healer. ${ }^{32}$ Through the ages the word hampicamayoc has retained its importance as name for the local healer, a role that has been discussed extensively by Valdivia Ponce. In Aymara language the word colla camana was the equivalent of hampicamayoc. ${ }^{33}$

The name hampicamayoc is composed of hampi and camayoc. The word camayoc is a general indication for an official or functionary, while the main meaning of hampi is 'medicine', so the hampicamayoc is the official who deals with medicines. In some reports the word hampicamayoc is slightly corrupted, such as ambicamayo, which is the form used by Arriaga. Calancha uses the word anpicamayo while Poma de Ayala applies the term hanpicamayoc where hanpi is used as a synonym for hampi. The meaning of hampi (or hanpi) is more than just medicine. In compound words it is also used to denote a poison of botanical origin. So Poma de Ayala applies the name hanpiyoc for a sorcerer or healer-herbalist who had knowledge of medicines and especially of poisons. ${ }^{34}$ The verb 'hampictam upiyachini' means: 'to give a purge, or to cast spells, or to administer deadly poison'. The Quechua use of the name hampi is more consistent than the western languages where a plant is called either medicinal or poisonous while the same plant is often medicinal and poisonous, dependent on the dose. The word hampi is rather seldom used for poison while miu (or mio) is the more common to denote a poison. Gonçalez

abortion, but he does not specify which plants those were. Other chroniclers such as Valera, Polo, Cobo and Murua specify that the midwife was involved which seems likely because she knew about plants which could be used to facilitate childbirth. Some of them have, at higher concentrations, an abortifacient effect.

31 Gonçalez Holguín, 1952: 585. Calancha, 1974: 855.

32 Arriaga, 1968: 238. Morua, 1946: 78, 113. Poma de Ayala, 1980: 166.

33 Valdivia Ponce, 1975: 20-192.

34 Poma de Ayala, 1980: 247, 285. 
Holguín gives hanpiyoc, yuyumio or mio yuyu as translation for 'poisonous herb'. In Aymara language the situation is even clearer. In the Aymara dictionary of Bertonio the meaning of colla is both 'medicine' and 'poison to kill'. The words hampicamayoc and colla camana might thus either mean 'official who applies medicines' or 'official who applies poison'. This is not surprising because these healers had a large knowledge of plants which could be medicine or poison, dependent on the concentration. ${ }^{35}$

Although it was not the only feature of a hampicamayoc, the knowledge of medicinal plants for curing was a distinguishing mark. On several occasions the chroniclers make statements which are illustrative for the importance of the knowledge of medicinal products and the profession of herbalist in the eyes of the Incas. Garcilaso gives a statement of the Inca ruler Pachacutec:

...the physician or herbalist who is ignorant of the virtues of herbs, or who knows the virtues of some but does not seek to know the virtues of all, knows little or nothing. He must work until he knows them all, whether useful or injurious, in order to deserve the title he lays claim to... ${ }^{36}$

Another chronicler reports about the fourth Inca ruler:

...they say that [the Inca ruler] Mayta Capac Ynga was a great scholar, who knew all medicines... ${ }^{37}$

The Incas themselves had no written history and the oral tradition had the tendency to idealize the Inca rulers. Though these statements are thus not necessarily true, they are nevertheless illustrating. This also applies to the fables of the Incas, written down by Molina:

...the Creator who was said to be the father of (the Inca) Ymaymana Viracocha, sent the latter out... to teach the people which (plants) were good for food and medicine and which should be avoided. He also gave names to all herbs and explained which had healing virtues and which were poisonous... ${ }^{38}$

The interest for medicinal plants is not that surprising because for the ill it represented a major source for medicines and thus a possibility to survive.

Although the hampicamayoc used some magic and prayers during his cure, their specialty was the knowledge and application of medicinal plants. It is possible that the latter contributed to a more positive evaluation of the hampicamayoc by the Spaniards than the other types of healers. Calancha tells that

\footnotetext{
35 Gonçalez Holguín, 1952: 145, 636. Bertonio, 1612: 50.

36 Garcilaso, 1966: 397.

37 Santacruz Pachacuti, 1992: 207.

${ }^{38}$ Molina, 1989: 54.
} 
the (h)anpicamayocs, who were called oquetlupuc in some coastal regions, were healers with a good reputation. After the conquest their knowledge of medicine and medicinal plants was even acknowledged and praised by the Catholic Church on the Council of Lima. ${ }^{39}$ The services of the hampicamayoc were generously rewarded but their function had, at least in some provinces, a serious drawback, as noted by Calancha. When the patient died and the relatives had the impression that the healer was partly or wholly to blame for it, they killed him cruelly and placed his body on the grave of the patient, so that the birds of prey devoured his dead body. The custom was described for the region of Pacasmayo so it seems that Calancha referred to a Chimú rather than an Inca custom. Murua gives a comparable version of the fate of a bad healer but adds that the possessions of the healer were given to the relatives of the patient. ${ }^{40}$

The Inca ruler had an enormous power and was venerated as a demi-god because he was supposed to be a descendant of the Sun god Inti. In his service were several hampicamayocs and the ruler did not undertake a journey without the company of one of them. It underlines the indigenous appreciation for the hampicamayoc and his role as official healer. In the report by Murua some other information is given about the many hampicamayocs in service of the ruler. The healers were not allowed to cure other people, or to let blood, or to draw teeth without the permission of the ruler. Taken the other way around it indicates that at least some of the hampicamayocs acted as a dentist. It thus seems that the hampicamayoc was not exclusively an expert on medicinal plants but that he also performed other medical interventions. The rather cryptic description of the hampicamayoc by Poma de Ayala and the clear translation of the word by Gonçalez Holguín (Table 1) suggest that he also acted as a kind of surgeon. ${ }^{41}$

About the transmission of the knowledge of medicinal plants Garcilaso gives some information. He further suggests that the abilities of the hampicamayoc -he does not mention that name but from the description it appears likely that he was meant- were mainly for the upper social classes:

...These purges and bleedings were performed by the most experienced of them, especially by old women (as midwives are here) and by great herbalists who were very famous in the days of the Incas. These herbalists learnt the virtues of many herbs, and taught them by tradition to their sons: they were regarded as doctors, who were not supposed to cure anyone, but only kings, the royal family, and the chiefs and their relatives. The ordinary people cured one another by what they had heard tell of medicine... ${ }^{42}$

\footnotetext{
39 Calancha, 1974: 1248.

40 Morua, 1946: 113.

41 Ibidem: 78-79. Poma de Ayala, 1980: 166.

42 Garcilaso, 1966: 121.
} 
It thus seems that the medical care for people with influence was far better than for the common people but that applies to many cultures. For a long time Garcilaso was one of the major informants about Inca culture but there are a number of inconsistencies in his reports. That is even true for the citation given above because on another place in his work he tells about the childbirth among Inca women:

...they gave birth without midwives, who were unknown: if someone undertook the profession, it was a witch rather than a midwife... ${ }^{43}$

There is a clear difference in the ordeal about the midwife in these two statements even if it was indeed true that Inca women gave very easily birth, as compared with Spanish women. ${ }^{44}$

The selection of people to become a healer resembled that of priests. One would expect that among the Incas, where religion played a decisive role in all aspects of life, the function of priests required a thorough selection and education. That was true for a few high-ranked priests who served the temples in Cuzco or the major oracles. These priests belonged to the upper social classes and had often ties with the royal family. For the lower ranks however, people were selected who were not able to perform other duties. For that reason many priests were old. The same applied to healers or magicians who cured with prayers and incantations. The description of Calancha is illustrative:

...There were many sorcerers in Peru. That was the reason that the Inca ruler ordered in his laws that all people had to work and to eat the sweat of their hands. The people who were handicapped or lamed, who were disfigured or were otherwise unable to work or to serve in the army had to learn the job of herbalist to cure diseased people or had to become sorcerer to serve as priests for their idols... ${ }^{45}$

For Calancha the Inca priest was simply a 'sorcerer'. Some other chroniclers such as Arriaga confirm the statement of Calancha. Divination and diviners played a major role in Inca society but the majority of the diviners (at least of the lower functions) were old and had obtained that function because they were not longer able to do other work. Religion and medicine were very important but the Incas were also very practical in the sense that people who could work on the field or in the army were not selected for a full-time job in the lower ranks of priests, diviners or healers. ${ }^{46}$

${ }^{43}$ Garcilaso, 1966: 213.

${ }^{44}$ Matienzo, 1967: 17. Lope de Atienza, 1931: 104-105. Matienzo tells that when the time for women was there they gave birth alongside the road, washed the baby, placed the baby upon the cargo, and proceeded their way.

${ }^{45}$ Calancha, 1974: 855.

46 Arriaga, 1968: 207. Cobo, 1964: 222-225. 


\section{Surgeons}

Many archeological findings indicate that surgery has a very long history in pre-Columbian South America and dates from long before the Incas. ${ }^{47} \mathrm{Cra}-$ nial surgery was of high quality as can be derived from the many recoveries after skull trepanation. Trepanation is the best-known part of pre-Columbian surgery because of the many skeletons which have survived the centuries and from which a large part was trepanned. There is in addition some evidence that other forms of surgery were practiced. On the pottery of pre-Inca Moche culture relatively often persons with an amputated arm or leg, and sometimes provided with an artificial limb, are depicted. Osteological analyses of Moche skeletal remains have shown that foot amputation with subsequent healing are likely in several cases. Poma de Ayala gives the figure of a person with one leg, possibly amputated, but here no prosthesis was depicted. Further archeological evidence for extensive surgical operations comes from the large number of instruments which were probably used in surgical operations. These instruments, found on several locations and now exhibited in museums, are different types of needles, tumi-knifes, and other objects which could be used in surgical operations. ${ }^{48}$

The Spaniards were surprised that the Incas applied bleedings as a tool to improve the condition of a patient. Because bleedings were in fashion in Europe at that time, they considered it as a proof of the high standard of Inca medicine. The application of bleedings can be considered as a basic form of surgery. The Incas used very thin needles, mostly flint points, to cause bleeding. ${ }^{49}$ When they had pain in the head they bled themselves between the eyebrows above the bridge of the nose. The jugular vein was often used, but never the veins of the arms. The bleedings were performed by experienced healers indicated with a specific name: circay camayok. ${ }^{50}$ The term is derived from the word circana, which was the name of the flint points used to perform bleedings.

While Gonçalez Holguín translates in the Spanish-Quechua section 'healer' as hampicamayoc, he translates hampicamayoc in his Quechua-Spanish section as 'healer, surgeon'. ${ }^{51}$ It indicates that the hampicamayoc also functioned as a surgeon. The same source gives the name chukri hampicamayok or chukrihampik for a surgeon. The name was derived from the words chukri hampiyachay,

\footnotetext{
47 Rifkinson-Mann, 1988: 411-416. Rytel, 1956: 365-369. Verano, 2000: 177-188.

48 Verano, 2000: 177-188. Poma de Ayala, 1980: 176.

49 Cobo, 1964: 14-X. Garcilaso, 1966: 120.

50 Garcilaso, 1966: 121. Gonçalez Holguín, 1952: 84.

51 Gonçalez Holguín, 1952: 145, 585.
} 
meaning surgery. The inclusion of hampi in the name for surgeon is striking. Although the word hampi in compound words could have some meanings it suggests that (botanical) medicines played a role during surgery. That is not surprising because the high percentage of recovery among patients with trepanned skulls indicates that the healer used medicinal plants to prevent infection and inflammation and possibly also analgesics to reduce pain during the operation.

Archeology does not provide information about some aspects of surgery. Because of the absence of written reports which deal with Inca (and pre-Inca) surgery we must use indirect ways to get information about some practical aspects of this part of medicine, such as anesthesia and prevention of infection, which means that any statement about these aspects have a high degree of speculation. Because the Incas were well aware of the medicinal properties of coca (Erythroxylum coca) it has been suggested that coca was used for its (local) anesthetic properties. However, there are no written reports which support such a view. There are nevertheless a few reports about situations where the ancient Peruvians felt the need to eliminate feelings of pain, namely during human sacrifices. Although not as frequent as the Aztecs, the Incas made human sacrifices and these were mostly young children. ${ }^{52}$ Before the children were strangled or buried alive they were anesthetized with intoxicating chicha. The same occurred with the many servants and secondary wives who had to follow their lord into death after their lord had died. ${ }^{53}$ Common chicha had a low alcohol percentage and was not suitable to intoxicate let alone to anesthetize, but the Incas knew means to enhance the alcohol content which resulted in a beverage called sora or viñapu. Another method to make chicha highly intoxicating was the addition of other plant products such as hallucinogens to chicha. The use of such a product is suggested by a report of Xerez where it is described that victims for human sacrifice were intoxicated so that they entered into death with great pleasure. ${ }^{54}$ It seems therefore likely that the same procedure was followed during surgical interventions and that highly intoxicating chicha, either with high alcohol content or with additions of hallucinogens, was used to keep the patient in a state that he could endure the surgical treatment. Alarco de Zadra describes the espingo as a medicinal plant with anesthetic properties. According to him chicha to which espingo seeds had been added, were in the past given to patients before a surgical operation. ${ }^{55}$ Some of these colonial applications are a continuation of the Inca

\footnotetext{
52 Betanzos, 1996: 132. Cobo: 1990: 8, 151. Molina, 1943: 55-56.

${ }^{53}$ Cobo, 1964: 131-135. Santa Cruz Pachacuti, 1992: 234.

54 Xerez, 1985: 90.

55 Alarco de Zadra, 1988: 56.
} 
custom to add espingo seeds to chicha which resulted in a highly inebriating mixture that served as an offering to the supernatural forces. ${ }^{56}$

Prevention of infection and inflammation is essential for a successful surgical intervention. It seems conceivable that for the prevention of infection the same substances were used as those which were applied in the embalming process of the Inca rulers after their death. ${ }^{57}$ Because these substances, such as menthol, tannins, certain saponins and resins are excellent antiseptics it is permissible to presume that the indigenous surgeons used plants, which contained these substances, externally in surgical treatments. Rifkinson-Mann suggested that extracts of the ratanhia tree (pumacuchu, Krameria triandra) were used to obtain hemostasis because this plant is rich in tannic acid. The Incas knew a whole series of plants against inflammation, such as aca-aca, asipa (Pachyrhizus tuberosus), canayuyo (Sonchus oleraceus), caralahua (Nicotiana glauca), cochayuyo (Durvillaea antarctica), hoccururo, oca (Oxalis tuberosa), ulluco (Ullucus tuberosus), quinoa (Chenopodium quinoa), rata-rata (Opuntia sulphurea), ticsau (Tropaeolum majus), tipa (Tipuana tipu), totora (Scirpus spp., Typha spp.), tulquina and yucaquiscas. ${ }^{58}$ It seems likely that these plants were applied to prevent or to treat inflammations as a result of surgical interventions.

\section{Trepanation}

Several ancient cultures of South America practiced trepanation (trepanning, trephining), thus surgical operations where a hole was made in the skull to treat problems related with intracranial processes. Many studies were performed in the previous century with skulls from the coastal regions of Peru where the climatological conditions favored the preservation of skeletal remains for a very large number of years. The oldest evidence of trepanation is a skull dating from 3000 B.C. from the region of Paracas. Trepanation was widely practiced in the Paracas and Nazca culture. Though pictures on

${ }^{56}$ Arriaga, 1968: 209-211. The botanical identification of espingo is not quite sure but several sources suggest that it is a Nectandra species, for example Nectandra pichurim. The problem is that the synonyms espingo and ishpingo are names which are used for several different types of trees such as Ocotea jelskii, Ocotea quixos, Amburana cearensis, Jacaranda copaia, Ajouea tambillensis and so on. Confusion also exists with espinco which is definite a completely different plant because it is an herb.

57 Mac Curdy, 1923: 217-330.

58 Rifkinson-Mann, 1988: 411-416. Cobo, 1964: 154-284. Losa, 1983: 23-138. Monardes, 1580: 2-98. Contreras y Valverde, 1983: 11-18. 
Mochica and Chimú pottery suggest that those cultures practiced trepanation, few trephined skulls were found in this region. ${ }^{59}$ Many systematic studies have been performed on skulls found in the highlands of Peru, including the region around Cuzco, where a large number of trephined skulls have been found, in spite of the less favorable conditions for their preservation in these regions. Many of the older studies concerning skeletal remains give no details about the age of these skeletons. It was therefore often not possible to discriminate between trepanations carried out in Inca times, or in pre-Inca times. Recent studies have shown that many trepanned skulls date from the time that the Incas ruled over the region, including many of the trepanned skulls in the Cuzco area. ${ }^{60}$ However, for some reason or other this significant feature of Inca medicine escaped to the attention of the chroniclers, because none of them mentioned trepanation. ${ }^{61}$

It is noteworthy that trepanation was a practice that was carried out frequently all over Peru and over a very long period of time. In some areas, such as Chachapoyas, only a limited number of trepanned skulls were found but that could be due to the circumstance that here many trepanned skulls did not survive the centuries. ${ }^{62}$ In many studies the number of trepanned skulls as a percentage of the total number of skulls was very high, as was the percentage of skulls whose owner had lived on for a considerable time after the trepanation. ${ }^{63}$ That means that the operation was careful carried out by experienced surgeons. The extent of the area and the experience of the surgeons could point to a transmission of knowledge in time and space but hard evidence for such statements is missing.

About most pre-Columbian cultures such as Paracas we are so poorly informed that we can only guess about the reason why so many skulls were trepanned. For the Incas there was a very obvious reason for trepanation. Warfare was common among the Incas and, as mentioned before, resulted in severe fractures and head wounds due to the use of weapons like slings and clubs. It is conceivable that given the choice between dying a painful death and

59 Rytel, 1956: 365-369. Lastres, 1951: 192-199. Trelles, 1962: 538-545.

${ }^{60}$ Andrushko and Verano, 2008: 4-13. Nystrom, 2007: 39-51.

${ }^{61}$ Some aspects of Spanish medicine, such as bleedings and the use of purges, were also present in Inca cultures and the chroniclers considered these practices as examples of a high standing of Inca medicine. Both in Spanish and Inca culture medicinal plants were important in medicine. The Spaniards did not practice trepanation but it seems unlikely that they would not have recorded them if they had seen them. It seems more likely that other factors -secrecy, absence of trepanations at the time of the conquest- played a role in the absence of records.

${ }^{62}$ Verano, 2000: 177-188. Nystrom, 2007: 39-51.

${ }^{63}$ Rogers, 1938: 321-340. 
performing a risky operation one might have opted for the last possibility. This hypothesis, which has been presented before, is hard to prove. Furthermore, in some parts of Peru a relatively large number of trepanned skulls were from females. Another possibility is that the high frequency of trepanation was a consequence of skull deformation which was practiced by many cultures in ancient Peru. ${ }^{64}$ Deformation of the skull could have resulted in compression of parts of the brain and problems in later phases of life. It could be that trepanations were meant as a kind of decompression, carried out for the relief of mental conditions due to deformities of the skull.

Because the chroniclers do not report about trepanation we know very little about the surgeons who carried out these operations. Analysis of the trepanned skulls shows that several trepanation techniques were followed, such as scraping, sawing, cutting, drilling, or a combination of these actions. On several archeological locations materials as tumis, scalpels, obsidian knifes and other objects have been found which were supposed to be used for surgical operations ${ }^{65}$ On Moche and Chimú pottery scenes are depicted which seem to represent a surgeon who operates a skull, but unfortunately trepanned skulls are rare on the northern coast of Peru. ${ }^{66}$

The observation that a large percentage of the trepanned skulls show healing and that the patient thus lived on after the operation proofs that the surgeons of ancient Peru must have been very skilled. This idea is further supported by the fact that in a number of cases trepanation was carried out more than one time on the same person. Mac Curdy reports about the skull of a male which bore the scars of no less than seven encounters with enemies and subsequently with surgeons, none of which proved fatal. Though the skull described by Mac Curdy is an exception, there are many skulls which have been trepanned twice. ${ }^{67}$ The recovery after trepanation shows that not only the surgeons were

${ }^{64}$ Mac Curdy, 1923: 217-330. Calancha, 1974: 1469. Morua, 1946: 169.

${ }^{65}$ Lastres, 1951: 178-223.

${ }^{66}$ The Incas were the last of a series of impressive civilizations which influenced each other and that of the Incas. The Incas integrated many attainments of previous cultures into their own. The healing practices belong to these attainments although it is not quite clear which practices were taken oven and how this was accomplished. Examples are the trepanation practices which were common in several parts of Peru. The chroniclers did not record these practices for the Incas but from archeological studies we know that the Incas too practiced trepanation. Cranial deformation is another example from which we know that it was widely practiced in the cultures preceding that of the Incas, as well as by the Incas themselves. It seems therefore likely that the medical customs of preceding cultures were taken over by the Incas, but unfortunately we are not familiar with the extent of that transmission, or about changes that were introduced.

67 Mac Curdy, 1923: 217-330. 
highly skillful but also that adequate measures were taken to keep the patient sedated during operation and that infection was prevented.

\section{Conclusions}

The large number of Quechua and Aymara names for indigenous healers suggests that there were many types of medical practitioners in ancient Peru who cured in different ways, using a variable amount of religion, magic and empirical knowledge of medicinal plants and surgical abilities in their cures. It seems that the hampicamayoc was of all those practitioners the one who most corresponded with the European healer of that time. A thorough knowledge of medicinal plants was of primary importance for the hampicamayoc but the reports suggest that he also performed surgical interventions. It seems however, that some surgery was performed by others, such as the performance of bleedings by the circay camayok. It is not clear whether the chukrihampik was a specialized kind of hampicamayoc or that it was his name when he performed surgical operations. The archeological evidence indicates that cranial surgery was quite successful. The ancient Peruvian surgeons had thus apparently a large experience, and it could mean that this class of healers was mainly (or exclusively) dealing with surgical interventions. A number of the medical practitioners mentioned in Table 1, such as the camasca, had only a partial relevance for medicine in the sense as we see it now. Their approach of curing the sick was mainly based on magic and religion. It would therefore be more appropriate to call them priest or magician than healer. It is questionable whether the common Incas considered them as less important in the curing process than the hampicamayoc. The Incas were a very pious people and strongly believed in the effectiveness of religious and magic acts. It seems plausible that this had a positive effect on the healing procedure. ${ }^{68}$

One of the problems with the Spanish sources is that many chroniclers were prejudiced. That was of little importance when they described medicinal plants but became relevant when they described subjects where magic and religion were involved. The Inca belief that sin was the cause of diseases made

${ }^{68}$ The belief that the actions of the healer were useful was strengthened by the belief in Inca cosmology. Classen (1993: 136, 137) states that in Inca cosmology the structures and processes that govern the human body are also the basic principles of the Inca cosmos. In that view the healer of the human body had his place in the Inca cosmos. Even after death the human body retained its importance. It became a mallqui, a huaca with a certain degree of supernatural power. 
that religion and magic played a major role in Inca medicine. Religion and magic were always part of the treatment of a disease, even if the treatment was mainly done with medicinal plants by the hampicamayoc. This involvement is one of the main reasons that many reports about the Inca healers are negative. A few other factors played also a role in the negative reports. Midwives were sometimes involved in abortion because they knew about the plants which facilitated delivery and caused abortion. Some healers, both male and female, played furthermore a role in criminal practices. Some sources stress this property of the healer. ${ }^{69}$ The reason to ask a hampicamayoc as an intermediate for killing a person was not only his large knowledge of poisonous plants but -ironically- also the severe punishments for murder. Simply killing another meant that shortly afterwards the killer was executed. Because the Inca herbalists knew about plants which caused death after a given time it was nearly impossible to trace the offender. ${ }^{70}$ On the other hand, if one was caught when he killed another with poisonous plants, not only he but his whole family was killed as well.

The information about Inca healers is not only prejudiced but also very incomplete. For a part that is due to the negative attitude of the Spaniards towards Inca religion and magic. Another reason is that the chroniclers in South America had not the qualities which, for example, the chroniclers for the Aztec region had. This applies to many aspects of society but certainly also to medicine and the use of medicinal plants. Chroniclers like Sahagún and Hernández recorded far more medicinal plants and gave much more information about Aztec medical abilities than those who reported about the Incas. That could be the reason that they did not observe trepanation. While it is now clear that trepanation was practiced by the Incas, there is no mentioning of it in the Spanish reports. ${ }^{71}$

The position of the healer in Inca society depended on his background and qualities. Those who mainly cured with magic were considered as a kind of priests who had some connection with the supernatural. Inside the group indicated as hampicamayoc the differences were considerable and the appreciation and standing depended mainly on their knowledge of plants. At the upper

69 Poma de Ayala, 1980: 247-285.

70 Pizarro: 1978: 71. Elferink, 1999: 339-360.

71 While the literature about the healers among the Incas is somewhat meager, there is a lot of literature about contemporary folk medicine of Peru. However, here too stress is laid on the use of medicinal plants rather that the healers, which in modern times are considered as shamans.

It is noteworthy that the role of shamans is particularly important in the treatment of psychiatric disturbances (Dobkin de Rios, 1989 and Green, 1998). 
side were those who were connected with the royal court and were responsible for the well-being for the ruler. They were very skilled and were highly appreciated. On the lower side were poor and old people who had become healer because they had to earn a living, as described by Calancha. ${ }^{72}$ Because they had learned the qualities of medicinal plants at an advanced age, their knowledge of medical affairs was limited and consequently they will have had a much lower status. The same applies to those who committed malevolent practices.

Whether the care of the Inca healers concerned the whole population or was reserved for the upper social classes is a question that is hard to answer satisfactorily. In his discussion of the pre-Columbian healers Coury refers to Garcilaso who stated that all sciences (thus also the medical sciences) was the area of the elite. ${ }^{73}$ In his treatise about shamanism and ritual healing among the ancient cultures of Peru Andritzky gives a thorough overview about the magicreligious background of healing among all ancient cultures in western South America. He mentions the elite-schools in Cuzco and suggests the possibility that here healers were trained. Although this suggestion could quite be true, it is not confirmed by the Spanish chroniclers. It was indeed true that the best healers were in service of the ruler but it seems unlikely that there were no healers for the common people. Based on a report of Poma de Ayala, that all Incas were divided in subclasses among which one for the ill and handicapped, Andritzky suggest the existence of a therapeutic community, which included all people. ${ }^{74}$ It is certainly true that a certain amount of care was given to the ill and handicapped but it is far from sure that healers were informed in this care. ${ }^{75}$

In colonial and recent times indigenous healers are often denoted as shamans, but depending on the definition of 'shaman', it is questionable whether the Inca healer can be called shaman. There are evidently many parallels between the Inca healer or hampicamayoc and the modern shaman ${ }^{76}$. Like the con-

${ }^{72}$ Calancha, 1974: 855.

${ }^{73}$ Coury, 1969: 190.

74 Andritzky, 1989: 250-252.

75 Relatively little attention has been paid by modern investigators to the role of the Inca medical practitioners. There is a reasonable amount of information available about neurosurgeons, based on archeological evidence (Verano, 2000; 2003. Marino, 2001). Most information about Inca medicine refers to the use of medicinal plants with an occasional remark about medical practitioners (Oblitas Poblete, 1971. Cabieses, 1993). The situation is different for contemporary folk medicine where appropriate attention has been paid to indigenous healers (Bastien, 1987. Polia Meconi, 1996).

${ }^{76}$ The Andean civilizations have a strong sense for continuity which made that some traditions persisted for a long time after the conquest up to modern times. This is most apparent among the healers which have developed into a kind of shaman who distributes medical knowledge and medicinal plants for all types of people (Bastien, 1987. Cabieses, 1993). It 
temporary shaman the Inca healer had an intermediate role between the natural and supernatural world and applied magic to make cures possible. However, the contemporary shaman has in his community also a considerable authority and power and is usually an ecstatic figure. In the highly organized state of the Incas where the ruler had all authority there was no room for ecstatic persons who had large influence on the live in a village. That was only reserved for the officials appointed by the ruler. These officials were part of a highly organized hierarchy so that both the state and his inhabitants were controlled by the ruler.

\section{BIBLIOGRAPHY}

Acosta, José de, Historia natural y moral de las Indias, México, Fondo de Cultura Económica, 1979.

Alarco de Zadra, A., El libro de las plantas mágicas. Compendio de Farmacopea popular, Lima, Concytec, 1988.

Andritzky, W. Shamanismus und rituelles Heilen im alten Peru. Band 1: Die Menschen des Jaguar. Band 2: Viracocha, Heiland der Anden, Berlin, Verlag Clemens Verling, 1989.

Andrushko, V. A. and Verano, J. W., "Prehistoric trepanation in the Cuzco region of Peru: A view into an ancient Andean practice", American Journal of Physical Anthropology, CXXXVII/4 (Minneapolis, 2008): 4-13.

Arriaga, Pablo Jose de, Extirpación de la idolatria del Piru, Madrid, Ediciones Atlas, 1968.

Bastien, J. W, Healers of the Andes. Kallawaya herbalists and their medicinal plants, Salt Lake City, University of Utah Press, 1987.

Bertonio, Ludovico, Vocabvlario dela lengva Aymara, Compañia de Jesus, Chuquito, 1612. http://www.uflib.ufl.edu/ufdc/?b=UF00076719\&v=00001. (Fecha de consulta: $1 / 06 / 2015)$.

Cabello Valboa, Miguel, Misceláea Antártica. Una historia del Peru antiguo, Lima, Universidad Nacional Mayor de San Marcos, 1951.

Cabieses, F., Dioses y enfermedades. La medicina en el antiguo Peru, vols. I and II, Lima, Edicionese Impresiones Artegraf, 1974.

Cabieses, F. Apuntes de medicina tradicional. La racionalización de lo irracional, Lima, A\&ditores, 1993.

seems likely that this tradition is a continuity of the situation in ancient Peru, and that healers also cared for common people among the Incas. 
Calancha, Antonio de la, Cronica moralizada del orden de San Agustín en el Peru, Lima, Universidad Nacional de San Marcos, 1974-1981.

Classen, C., Inca cosmology and the human body, Salt Lake City, University of Utah Press, 1993.

Cobo, Bernabe, Historia del Nuevo Mundo, Madrid, Ediciones Atlas, 1964.

Contreras y Valverde, Vasco de, Relación de la Ciudad del Cusco, Cuzco, Imprenta Amauta, 1983.

Coury, C., La médecine de l'Amérique precolombienne, Paris, Les Editions Roger Dacosta, 1969.

Dobkin de Rios, M., "A Modern-Day Shamanistic Healer in the Peruvian Amazon: Pharmacopoeia and Trance", Journal of Psychoactive Drugs, XXI/1 (Milton Park Abingdon, 1989): 91-99.

Domingo de Sancto Thomas, Fray, Grammatica o arte de la lengua general de los Indios de los Reynos del Peru, Madrid, Ediciones de Cultura Hispanica, 1994.

Elferink, J. G. R., "The use of poison and malevolent magic in criminal practices among the Incas in pre-Columbian Peru", Colonial Latin American Historical Review, VIII/3 (Albuquerque, 1999): 339-360.

Garcilaso de la Vega, El Inca, Royal Commentaries of the Incas and general history of Peru, Austin, University of Texas Press, 1966.

Gonçález Holguín, Diego, Vocabvlario de la lengva general de todo el Perv llamada lengua Qquichua o del Inca, [1608], Lima, Imprenta Santa Maria, 1952.

Greene, S., “The Shaman's Needle: Development, Shamanic Agency, and Intermedicality in Aguaruna Lands, Peru", American Ethnologist, XXV/4 (Indianapolis, 1998): 634-658.

Lastres, J. B., Historia de la Medicina Peruana. Vol. I. La medicina Incaica, Lima, Imprenta Santa Maria, 1951.

Lope de Atienza, “Compendio Historial del Estado de los Indios del Peru”, Jacinto Jijon y Caamaño (ed.), La Religion del Imperio de los Incas, Quito, Escuela Tipografica Salesiana, 1919, 1-448.

Losa Avila y Palomares, Gregorio de, De los arboles; frutos; plantas; aves y de otras cosas medicinales... tiene este reyno, La Paz, Sociedad Geografica de La Paz, 1983.

MacCurdy, G. G., "Human skeletal remains from the highlands of Peru", American Journal of Physical Anthropology, VI/8 (Minneapolis, 1923): 217-330.

Marino, R. Jr. y Gonzales-Portillo M., "Preconquest Peruvian neurosurgeons: a study of Inca and pre-Columbian trephination and the art of medicine in ancient Peru" Neurosurgery, XLVII/4 (Philadelphia, 2001): 940-950. 
Matienzo, Juan de, Gobierno del Perú, Paris-Lima, Institut Français d'Etudes Andines, 1967.

Molina, Cristóbal de, Relación de las fábulas y ritos de los Incas, Madrid, Historia $16,1988$.

Morua, Martin de, Los origenes de los Incas, Lima, 1946. Los Pequeños Grandes Libros de Historia Americana, serie 1, tomo XI.

Murua, Martin de, Historia general del Perú, Madrid, Historia 16, 1987.

Nystrom, K. C., "Trepanation in the Chachapoya region of Northern Peru", International Journal of Osteoarchaeology, XVII/1 (Hoboken, 2007): 39-51.

Oblitas Poblete, E., Magia, hechicería y medicina popular boliviana, La Paz, Ediciones Isla, 1971.

Pizarro, Pedro, Relación del descubrimiento y conquista de los reinos del Peru, Lima, Pontificia Universidad Católica del Perú Fondo Editorial, 1978.

Polia Meconi, M., “Despierta, remedio, cuenta... ”: adivinos y médicos del Ande, vol. I y vol. II, Lima, Pontifica Universidad Católica del Perú, 1996.

Polo de Ondegardo, Juan, Los errores y supersticiones de los Indios, Lima, Colección de libros y documentos referentes a la historia del Perú, tomo III, 1916.

Poma de Ayala, Felipe Guaman, El Primer Nueva Corónica y Buen Gobierno, Edición crítica de J. V. Murra y R. Adorno, México, Siglo Veintiuno Editores, 1980.

Prieto, Andres, I. Missionary Scientists. Jesuit Science in Spanish South America, 1570-1810, Vanderbilt, University Press, 2011.

Relación de los Agustinos de Huamachuco, Relación de la religión y ritos del Perú hecha por los padres agustinos, Lima, Pontifica Universidad Católica del Perú Fondo Editorial, 1992.

Rifkinson-Mann, S., “Cranial surgery in ancient Peru”, Neurosurgery, XXIII/4 (Philadelphia, 1988): 411-416.

Rogers, S. L., "The healing of trephine wounds in skulls from pre-Columbian Peru", American Journal of Physical Anthropology, XXIII/3 (Minneapolis, 1938): 321-340.

Rytel, M. M., "Trephinations in ancient Peru" Quarterly Bulletin of the Northwestern University Medical School, XXX/4 (Chicago, 1956): 365-369.

Santacruz Pachacuti Yamqui, Juan de, Relación de antigüedades deste reino del Perú, Madrid, Historia 16, 1992.

Trelles, J. O., "Cranial trepanation in ancient Peru”, World Neurology, III/5 (Amsterdam, 1962): 538-545.

Valera, Blas, Las costumbres antiguas del Perú y "La historia de los Incas", Lima, 1945. Los pequeños Grandes Libros de Historia Americana, serie I, tomo VIII. 
Valdivia Ponce, O., Hampicamayoc. Medicina Folklorica y su Substrato Aborigen en el Perú, Lima, Universidad Nacional Mayor de San Marcos, 1975.

Verano, J. W.; Anderson, L. S. and Franco, R., "Foot amputation by the Moche of ancient Peru: Osteological evidence and archaeological context", International Journal of Osteoarchaeology, X/3 (Hoboken, 2000): 177-188.

Verano, J. W., "Trepanation in prehistoric South America: geographic and temporal trends over 2000 years", R. Arnott, S. Finger and C. Smith (eds.), Trepanation: History, discovery, theory, Leiden, Swets and Zeitlinger, 2003: 223-236.

Xeres, Francisco de, Verdadera Relación de la Conquista del Perú, Madrid, Historia 16, 1985.

Fecha de recepción: 22 de agosto de 2012.

Envíos de modificaciones: 7 de mayo de 2013 y 15 de octubre de 2013.

Fecha de aceptación: 26 de octubre de 2013.

\section{El médico Inca: conocimiento empírico y magia en el Perú precolombino}

La posición social de los profesionales de la medicina en la Cultura Inca se conoce gracias a los hallazgos arqueológicos y, sobre todo, gracias a los escritos de los cronistas españoles. En la medicina Inca, la religión y la magia ocupaban un papel destacado, aunque también era importante el conocimiento de las plantas medicinales. En consecuencia, existieron distintos tipos de curanderos que curaban con una mezcla más o menos mayor de plantas medicinales y ceremonias religiosas y mágicas. El hampicamayoc o «funcionario encargado de los medicamentos» sobresalía entre los curanderos y tenía cierto parecido con el médico europeo de la época. Su actuación se basaba sobre todo, aunque no exclusivamente, en el uso de plantas medicinales. Otros, en cambio, curaban básicamente con procedimientos mágicoreligiosos. La cirugía debió ser importante para el sanador Inca pero este hecho apenas se refleja en la obra de los cronistas españoles.

Palabras Clave: Inca; médico; medicina; magia; hampicamayoc. 